\title{
Pharmacotherapy review: a proposal to improve medication adherence among hypertensive patients
}

\author{
Cláudia Coelho Rigoni', Evelin Soares de Brito², Graziela Modolon Alano', Dayani Galato ${ }^{2, *}$
}

\author{
${ }^{1}$ Pharmacy Course, Center for Health Sciences, University of Southern Santa Catarina, Tubarão, Brazil, ${ }^{2}$ Pharmacy Course, \\ Sciences and Technology in Health PhD Program, University of Brasilia, Brazil
}

\begin{abstract}
Pharmacotherapy review is a structured assessment of medicines, which aims to obtain a partnership with patients to achieve drug treatment goals and agreement about drug dosage, as well as when and how the drugs should be administered. The objective was to analyze the influence of pharmacotherapy review, by scheduling drug administration to improve medication adherence among antihypertensive patients. This study was an uncontrolled intervention developed in three distinct stages. The first stage included data collection on the profile of patients and their medications, and a preliminary assessment of medication adherence. In the second stage, the review report was delivered to patients. In the third stage, the results of blood pressure and medication adherence were assessed. The influence of the revision was measured through statistical tests $(\mathrm{p}<0.05)$. The study included 40 patients with a mean age of 58.0 (SD:11.3) years; $72.5 \%$ were women. Thirty-three (82.5\%) patients required some intervention, after when there was a significant increase in the number of daily doses $(p=0.039)$ and drug intakes $(\mathrm{p}=0.025)$. There was a significant increase in the adherence rate, according to both the Morisky-Green test $(p<0.001)$ and self-reported assessment $(p=0.004)$. There was also an improvement in the levels of systolic $(\mathrm{p}<0.001)$ and diastolic $(\mathrm{p}=0.002)$ blood pressure and in the number of patients with controlled hypertension $(\mathrm{p}=0.006)$. The pharmaceutical service enhanced medication adherence and control of systemic blood pressure; however, it increased the complexity of treatment.
\end{abstract}

Uniterms: Pharmacotherapy review. Drugs/administration schedule. Hypertension/medication adherence. Medication adherence. Pharmaceutical assistance.

A revisão da farmacoterapia é uma avaliação estruturada dos medicamentos com o objetivo de proporcionar aos pacientes o alcance dos objetivos terapêuticos por meio da forma adequada de administração dos medicamentos. O objetivo foi analisar a influência da revisão da farmacoterapia, por meio do aprazamento dos medicamentos, na adesão à medicação e no controle da hipertensão arterial sistêmica. Trata-se de um estudo de intervenção não controlado desenvolvido em três momentos distintos. No primeiro, realizou-se a coleta de dados sobre o perfil dos pacientes e de suas medicações e a avaliação da adesão; no segundo momento, realizou-se a entrega do relatório da revisão aos pacientes e na terceira etapa avaliou-se o resultado da adesão e pressão arterial. A influência da revisão foi medida por meio de testes estatísticos $(\mathrm{p}<0,05)$. Participaram deste estudo 40 pacientes, com média de idade de 58,0 anos (SD:11,3), sendo 72,5\% mulheres. Dos pacientes, $33(82,5 \%)$ necessitaram intervenções. Após estas se verificou aumento significativo no número de doses $(\mathrm{p}=0,039)$ e no número de tomadas $(\mathrm{p}=0,025)$. Houve aumento significativo no número de aderentes tanto pelo teste de Morisky-Green $(\mathrm{p}<0,001)$ quanto na avaliação autorreferida $(\mathrm{p}=0,004)$. Também, houve melhora nos níveis de pressão sistólica $(\mathrm{p}<0,001)$ e diastólica ( $\mathrm{p}=0,002)$ e no número de pacientes com a pressão controlada $(\mathrm{p}=0,006)$. O serviço farmacêutico desenvolvido promoveu aumento da adesão e do controle da pressão arterial, no entanto, aumentou a complexidade do tratamento.

Unitermos: Revisão da farmacoterapia. Fármacos/esquema de administração. Hipertensão/adesão à medicação. Medicação/adesão. Assistência farmacêutica.

\footnotetext{
*Correspondence: D. Galato. Programa de Pós-Graduação em Ciências e Tecnologias da Saúde. Universidade de Brasília. Centro Metropolitano, conjunto A, lote 01, Prédio Unidade de Ensino e Docência - 72220-900 - Ceilândia Sul

- Brasília - DF, Brasil. E-mail: dayanigalato@unb.br
} 


\section{INTRODUCTION}

The treatment of hypertension, which is a common chronic condition among adults, is generally continuous and uses drug combinations, either to treat the disease, or to reduce cardiovascular risk factors and manage complications. This feature increases the complexity of the treatment resulting in low rates of medication adherence and control of pressure levels (Trauthman et al., 2014; Correr, Soler, Otuki, 2011; SBC, 2010; Ho, Bryson, Romsfeld, 2009).

Low adherence to antihypertensive treatment has been considered a major barrier to adequate blood pressure control (Holt et al., 2010; Ho, Bryson, Romsfeld, 2009), and consequently, the treatment becomes ineffective, leading to complications (Correr, Soler, Otuki, 2011; Ho, Bryson, Romsfeld, 2009; Osterberg, Blaschke, 2005).

The WHO (2003) defines medication adherence as a patient's degree of compliance in relation to what was prescribed or oriented by physicians or other health care professionals. Adherence is a complex behavioral process that is influenced by several factors (Porto et al., 2014; Luneli et al., 2009; Osterberg, Blaschke, 2005). Therefore, several instruments were developed to assess this outcome, including the Morisky-Green test (Morisky, Green, Levine, 1986).

In this context, the way people follow drug instructions is a big challenge, especially when it comes to chronic diseases, since it involves, in addition to use of various medications, change in behavior and dietary habits (Osterberg, Blaschke, 2005). Corroborating this information, the WHO (2003) estimates that $50 \%$ of patients forget to take their medications. In addition, surveys conducted in Brazil with hypertensive subjects showed that only one third adhered to medication therapy (Prado, Kupek, Mion, 2007; Bastos-Barbosa et al., 2012).

Pharmacotherapy review may be defined as a service that performs a review of medications used by patients in order to control risks and improve outcomes of drug therapy, detecting, resolving and preventing drug-related problems (Leikola et al., 2012). Thus, this service is a structured assessment of medicines, which aims to obtain a partnership with patients to achieve drug treatment goals and agreement about the dosage, as well as when and how the drugs should be administered (together with food or after a fast) (Miranda et al., 2012; Geurts et al., 2012; Holland et al., 2007). In this context, one of the important activities undertaken in this process is the drug administration schedule.

The aim of this study was to analyze the influence of pharmacotherapy review upon medication adherence and hypertension control in patients in a community pharmacy.

\section{METHODS}

\section{Research setting}

The research was conducted in a community pharmacy in a small town in southern Brazil. The town has just over ten thousand inhabitants according to the Brazilian Institute of Geography and Statistics (IBGE, 2010). With regard to healthcare facilities, there were five basic health units, linked to the Brazilian National Health System, which provided access to medical, nursing, dentistry, psychology, speech therapy, nutrition, pharmacy, acupuncture and physiotherapy assistance, in addition to four community pharmacies.

People residing in the municipality could have free access to medicines in the basic health units and in community pharmacies, provided that the patients had prescription drugs either standardized by the municipality or by the "health is priceless" program (a specific program for free distribution of drugs for hypertension, diabetes, and asthma) (Brasil, 2015).

The pharmacy in which the study was conducted is located downtown, has two pharmacists, in addition to the researcher of this study. This pharmacy provides clinical services, such as drug dispensing, indication of non-prescription medicines for self-care, orientation towards health promotion and rational use of medicines, among others. The establishment is also starting the implementation of pharmacotherapy review as a tool for promoting a more efficient and rational use of medicines.

\section{Study design (type of study)}

This is a non-controlled intervention study.

\section{Population and sample}

Patients were eligible for this study if they were diagnosed with hypertension and were taking antihypertensive medications for at least 30 days.

The sample size was calculated for a onetailed hypothesis test, i.e., the only hypothesis is that "the completion of the pharmacotherapy review and intervention will enhance adherence to medication." The significance level was set at 5\% and the test power at $80 \%$; the adherence rate was estimated to be $50 \%$ (Prado, Kupek, Mion, 2007) prior to the intervention and $70 \%$ after the intervention. With these parameters, the minimum sample size was estimated to be 36 subjects, 
but considering the losses and biases, an addition of $10 \%$ was made, resulting in a final sample of 40 subjects. The participants were selected by convenience sampling from patients enrolled in the "health is priceless" program of the popular pharmacy.

\section{Data collection instrument and procedure}

A structured interview previously tested in a pilot study was used to interview the patients. The pilot study was conducted with $10 \%$ of the sample previously calculated. Since no substantial changes were made, the data were included in the survey.

The research proposal was presented to the patients, who were asked to sign a free informed consent form. Only consenting subjects were interviewed.
The research was carried out in three stages (Figure 1). In stage 1, the patients were invited to participate in the study when they came to the community pharmacy; if he or she had no time available to do it, a home visit was scheduled to conduct the interview. In this first interview, the Morisky-Green test (Ben, Neumann, Mengue, 2012; Santa-Helena, Nemes, NetoEluf, 2008) was used to assess medication adherence. Participants were asked to grade their personal evaluation of adherence on a scale ranging from zero to 10 , with zero representing minimum medication adherence and 10 the maximum adherence rate. In addition, personal information was collected during the first interview, such as name, age, gender, education level, major and secondary diseases, medications used, concentration and dosage of medications, and if they were prescription drugs. If

\section{Stage 1}

Interview and questionnaire administration to collect sociodemographic data and information about medications, daily routine, physical activity, diet, control of sodium intake, stress and adherence assessment using Morisky-Green test and self-evaluation. Blood pressure measurement.

$\longrightarrow \begin{aligned} & 1^{\text {st }} \text { day } \\ & \text { Invitation to participate in the study } \\ & \text { Informed consent form } \\ & \text { Presentation of the research proposal }\end{aligned}$

Within four to six weeks after stage 2

FIGURE 1 - Development of the pharmacotherapy review. 
prescription drugs were reported, the patients were asked to present either the prescription or the card of the National Public Health System for verification. They were also asked about physical activity, diet and efforts to reduce sodium intake.

Patients were asked to describe their daily routine for the assessment of drug administration schedules. The daily routine description included activities from waking up through going to bed, such as meals, medications, and nap taking. This information was important to assess how the respondents were taking their medications and possible interactions with food and other drugs used concomitantly. During the interview, blood pressure was measured, according to the protocol established by the $6^{\text {th }}$ Hypertension Guideline (SBC, 2010), using a semiautomatic arm blood pressure monitor (Visomat ${ }^{\circledR}$ Comfort III), certified by the National Institute of Metrology, Quality and Technology (INMETRO) for Brazil. The choice of the brand followed the recommendations by the $6^{\text {th }}$ Guideline on Hypertension (SBC, 2010). All blood pressure measurements were performed by the researcher, and were recorded on a card designed for that purpose, which was delivered to the patient during the first meeting.

Based on these data, a thorough literature review was conducted on the medications used, emphasizing how to use, dosage, interactions with food and other drugs. Subsequently, the routine described by the patient was jotted down in the review report if no problem was encountered. In case there was a problem with the routine, an intervention was defined; whenever possible, we tried to interfere as little as possible with the patient's routine.

Stage 2 included a presentation of the review report to the patient. The report consisted of a document that organized the medications to be taken, the amount, schedule and nutritional care. When necessary, pictograms were used to facilitate information readability. Figure 2 presents a model of the review report, which was subsequently delivered to the patient together with a refrigerator magnet. During this second phase, the review suitability was evaluated with the patient or caregiver. During this meeting, a second blood pressure measurement was performed.

Stage 3 was performed within four to six weeks after stage 2. A new interview was held for reassessment of medication adherence using the Morisky-Green test (Ben, Neumann, Mengue, 2012; Santa-Helena, Nemes, Neto-Eluf, 2008), self-assessment, and blood pressure measurement. The patients were asked about where they had kept the review reports, their perception on the intervention and suitability of the pharmacotherapy review report.
The data collected during the interviews, the problems encountered in the patient's routine and interventions on the pharmacotherapy review for each patient were recorded on an instrument developed by the researcher for that purpose.

\section{Data organization and analysis}

Subjects were considered adherent if they responded negatively to all questions of the Morisky-Green test (Ben, Neumann, Mengue, 2012; Santa-Helena, Nemes, NetoEluf, 2008). As for self-assessment, adherent patients were those who scored equal to or greater than 8 . This score was set because patients are considered adherent if they comply with at least $80 \%$ of their treatment (WHO, 2003).

The clinical control over the disease was based on the blood pressure readings. All patients with blood pressure values below $140 \mathrm{mmHg}$ systolic and $90 \mathrm{mmHg}$ diastolic were considered controlled (Koenigsfeld et al., 2015), even patients with comorbidities present pressure goal with values less than 130/80 mm Hg (Hypertension (SBC, 2010). For the purpose of this study, blood pressure before the intervention was calculated by averaging the measurements obtained during the first and second meetings. The pressure after the intervention was calculated by averaging the measurements obtained during the third visit.

Additional diseases mentioned by the patients were categorized using the International Statistical Classification of Diseases and Related Health Problems (ICD-10) (WHO, 2010).

The classification of medications used by the patients was performed by using the Anatomic Therapeutic Chemical (ATC) classification developed by the WHO (2015).

The data collected were entered into the EpiData 3.1 software and were later analyzed using the EpiInfo 6.0 and Statistical Package for Social Sciences (SPSS) 19.0. The results were initially displayed descriptively; nominal variables were presented as absolute numbers and proportions, whereas numerical variables were presented as measures of central tendency and dispersion.

The Shapiro-Wilk test was initially used as a numerical means of assessing normality of the data for examining the influence of the pharmacotherapy review on adherence and clinical management of hypertension. The McNemar test was used to assess the influence of intervention upon categorical variables (proportion of adherent patients shown by the Morisky-Green test and proportion of self-reported adherence). Paired t-tests were used to assess numerical variables with normal distribution, whereas Wilcoxon test was used for numeric 


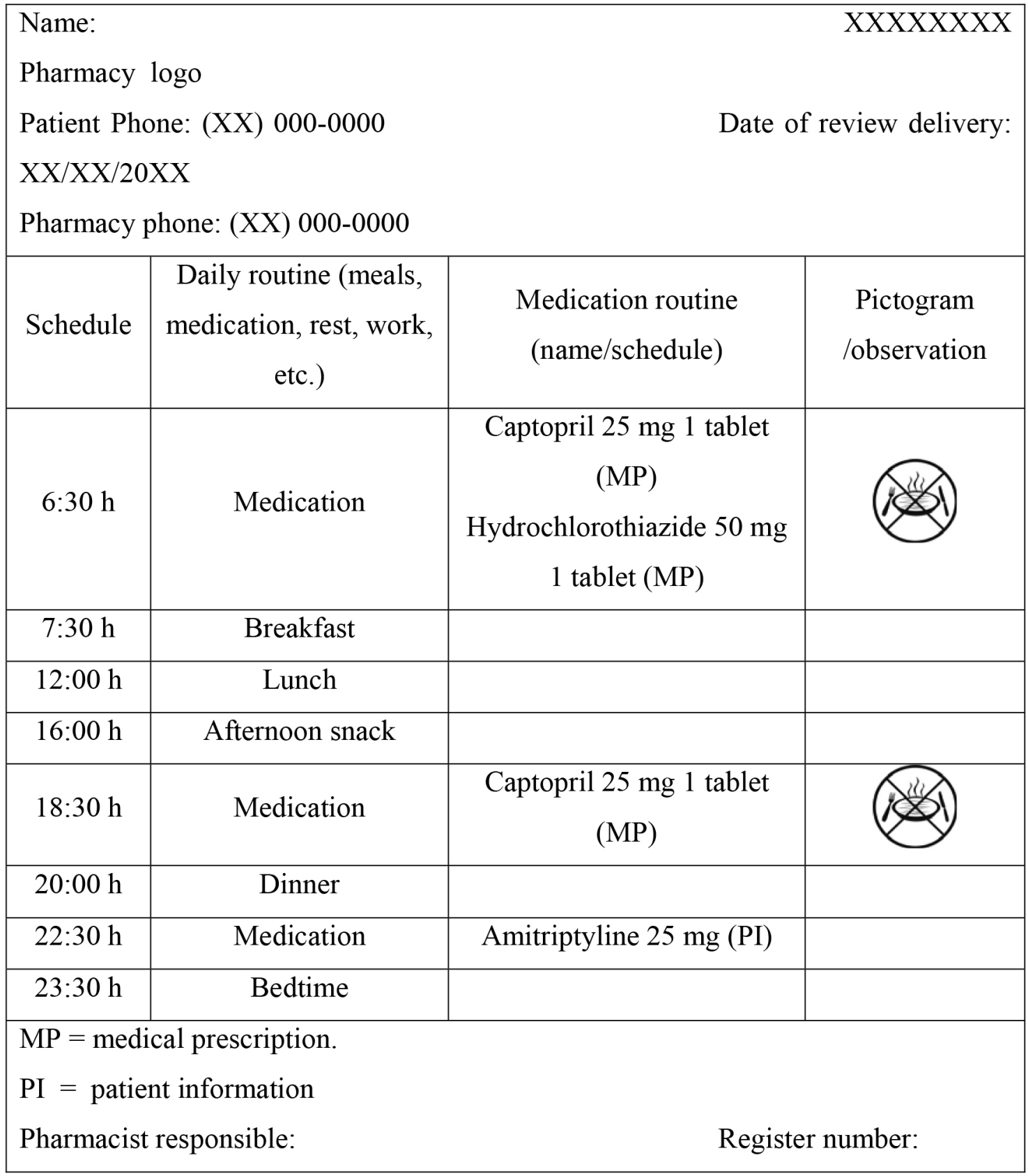

FIGURE 2 - Review report delivered to patients in stage 2.

variables with non-normal distribution; $p<0.05$ was considered to be statistically significant.

\section{Ethical considerations}

This project was designed in accordance with the recommendations of Resolution 196 of the Brazilian National Health Council. It was submitted to and approved by the Research Ethics Committee of University of Southern Santa Catarina under protocol number 12.414.4.03.III.

\section{RESULTS}

The study included 40 patients, whose mean age was 58.0 (SD: 11.3) years, ranging from 30 to 79 years. Further information about sociodemographic variables and behavioral characteristics of participants is shown in Table I.

Besides hypertension (HBP), which was a condition to participate in the study, the most common illnesses reported by patients were diabetes mellitus $(8 ; 20.0 \%)$, dyslipidemia (8;20.0\%), and cardiovascular disease 
TABLE I - Profile of participant adherence to treatment through pharmacotherapy review

\begin{tabular}{lc}
\hline Variable & $\mathrm{n} \%$ \\
\hline Gender & \\
$\quad$ Male & $11(27.5)$ \\
$\quad$ Female & $29(72.5)$ \\
Age ${ }^{a}$ & \\
$\quad$ Up to 59 years & $20(50.0)$ \\
$\quad 60$ years and above & $20(50.0)$ \\
Education & \\
$\quad$ Up to 8 years of schooling & $29(72.5)$ \\
9 years or more of schooling & $11(27.5)$ \\
Physical activity & \\
$\quad$ Yes & $14(35.0)$ \\
No & $26(65.0)$ \\
Sodium intake control & \\
$\quad$ Yes & $34(85.0)$ \\
No & $6(15.0)$ \\
\hline a Median
\end{tabular}

(7; 17.5\%). The classification of other health problems, according to the ICD-10 (WHO, 2010), is shown in Table II.

Overall, the participants were using 175 pharmaceutical products. Table III shows the description of drugs, according to the ATC classification system (WHO, 2015), specifying the main anatomical groups (level 1) and the main therapeutic groups (level 2).

According to the ATC classification (WHO, 2015), most drugs belonged to the cardiovascular system (C) $(101 ; 57.7 \%)$. Of these, drugs that acted on the reninangiotensin system were prevalent among the therapeutic group $(40 ; 22.8 \%)$, of which losartan was the most commonly used $(25 ; 47.5 \%)$.

The most frequently used psychoanaleptic and psycholeptic (anxiolytic) agents that act on the nervous system (N) $(39 ; 22.3 \%)$ were fluoxetine and bromazepam, respectively. In this group of patients, the prevalence of clonazepam use was $22.5 \%$ (9). Although this medication is classified as an antiepileptic drug, patients used it to treat insomnia. Among the drugs that act on the digestive

TABLE II - Health problems reported by patients, according to ICD-10 classification

\begin{tabular}{|c|c|c|}
\hline Title & $\begin{array}{c}\text { CID-10 } \\
\text { Disease categories }\end{array}$ & $\mathrm{n}(\%)$ \\
\hline \multirow{3}{*}{ Diseases of the circulatory system } & Hypertensive diseases & $40(100.0)$ \\
\hline & Ischemic heart disease & $7(17.5)$ \\
\hline & Cerebrovascular diseases & $1(2.5)$ \\
\hline \multirow[t]{2}{*}{ Endocrine, nutritional and metabolic diseases } & $\begin{array}{c}\text { Disorders of lipoprotein metabolism and } \\
\text { other dyslipidemias }\end{array}$ & $8(20.0)$ \\
\hline & Diabetes Mellitus & $8(20.0)$ \\
\hline \multirow{4}{*}{ Mental and behavioral disorders } & Nervous system diseases & $1(2.5)$ \\
\hline & $\begin{array}{l}\text { Neurotic stress-related and somatoform } \\
\text { disorders }\end{array}$ & $3(7.5)$ \\
\hline & Mood (affective) disorders & $4(10.0)$ \\
\hline & Mental and behavioral disorders & $1(2.5)$ \\
\hline \multirow[t]{2}{*}{ Respiratory diseases } & $\begin{array}{l}\text { Other diseases of the upper respiratory } \\
\text { tract }\end{array}$ & $1(2.5)$ \\
\hline & Lower respiratory tract diseases & $2(5.0)$ \\
\hline Digestive system diseases & $\begin{array}{c}\text { Diseases of esophagus, stomach and } \\
\text { duodenum }\end{array}$ & $1(2.5)$ \\
\hline \multirow{5}{*}{ Diseases of the musculoskeletal system and connective tissue } & Disorders of bone density and structure & $2(5.0)$ \\
\hline & Spinal disease (dorsopathy) & $1(2.5)$ \\
\hline & Arthritis & $2(5.0)$ \\
\hline & Rheumatism & $3(7.5)$ \\
\hline & Inflammatory polyarthritis & $1(2.5)$ \\
\hline Non-inflammatory disorders of the genitourinary system & Menopausal and perimenopausal disorders & $1(2.5)$ \\
\hline Other inner ear disorders & Labyrinthitis & $2(5.0)$ \\
\hline Other thyroid problems & Thyroid gland disorders & $1(2.5)$ \\
\hline
\end{tabular}


TABLE III - Drugs used by patients, according to the ATC classification

\begin{tabular}{|c|c|c|}
\hline Anatomical main group & Therapeutic main group & $\mathrm{n}(\%)$ \\
\hline \multirow[t]{2}{*}{ A-Alimentary tract and metabolism } & & $18(10.2)$ \\
\hline & $\begin{array}{c}\text { A02 - Drugs for acid related disorders } \\
\text { A10 - Drugs used in diabetes } \\
\text { A12 - Mineral supplements }\end{array}$ & $\begin{array}{l}3(1.7) \\
11(6.3) \\
4(2.3) \\
\end{array}$ \\
\hline \multirow[t]{2}{*}{ B-Blood and blood forming organs } & & $8(4.6)$ \\
\hline & B01 - Antithrombotic agents & $8(4.6)$ \\
\hline \multirow[t]{2}{*}{ C-Cardiovascular system } & & $101(57.7)$ \\
\hline & $\begin{array}{c}\text { C01 - Cardiac therapy } \\
\mathbf{C 0 2}-\text { Antihypertensive } \\
\text { C03 - Diuretics } \\
\text { C07 - Beta blocking agents } \\
\text { C08 - Calcium channel blockers } \\
\text { C09 - Agents acting on the renin-angiotensin system } \\
\text { C10 - Lipid modifying agents }\end{array}$ & $\begin{array}{c}4(2.3) \\
1(0.6) \\
25(14.2) \\
13(7.4) \\
4(2.3) \\
40(22.8) \\
14(8.0)\end{array}$ \\
\hline \multirow[t]{2}{*}{$\overline{\text { G- Genitourinary system and sex hormones }}$} & & $1(0.6)$ \\
\hline & G03 - Sex hormones and modulators of the genital system & $1(0.6)$ \\
\hline \multirow[t]{2}{*}{$\begin{array}{l}\text { H- Systemic hormonal preparations (excluding } \\
\text { sex hormones and insulin) }\end{array}$} & & $2(1.2)$ \\
\hline & H03 - Thyroid therapy & $2(1.2)$ \\
\hline \multirow[t]{2}{*}{ M-Musculoskeletal System } & & $5(2.8)$ \\
\hline & $\begin{array}{l}\text { M01- Antiinflammatory and antirheumatic products } \\
\text { M05- Drugs for treatment of bone diseases }\end{array}$ & $\begin{array}{l}4(2.3) \\
1(0.6)\end{array}$ \\
\hline \multirow[t]{2}{*}{ N-Nervous System } & & $39(22.3)$ \\
\hline & $\begin{array}{c}\text { N02- Analgesics } \\
\text { N03- Antiepileptics } \\
\text { N05- Psycholeptics (anxiolytics) } \\
\text { N06- Psychoanaleptics } \\
\end{array}$ & $\begin{array}{l}1(0.6) \\
9(5.0) \\
13(7.4) \\
16(9.0) \\
\end{array}$ \\
\hline \multirow[t]{2}{*}{$R$-Respiratory System } & & $1(0.6)$ \\
\hline & R03- Drugs for obstructive airway diseases & $1(0.6)$ \\
\hline Total & & $175(100.0)$ \\
\hline
\end{tabular}

tract and metabolism (A) $(18 ; 10.2 \%)$, those used for the treatment of diabetes mellitus, especially metformin, were the most frequently used drugs for 7 (17.5\%) patients. Acetylsalicylic acid (aspirin) was the only drug acting in the blood and blood-forming organ (B) that was used by $20 \%(8)$ of the patients.

Some cases of unusual doses found in this study included a sub-dose of glucosamine and chondroitin and a sub-dose of captopril. The concomitant use of medications from the same pharmacologic class was also identified in one case.

The number of drugs used by patients ranged from one to nine, having a mean of 4.4 (SD: 2.2) medications per patient. These figures remained unchanged after the interventions.
Table IV presents the results of the variables analyzed to assess the influence of the review of pharmacotherapy on the characteristics of treatment, adherence rate, and blood pressure control of the study participants.

Importantly, there was no significant difference between the blood pressure measurements between the Stage 1 and Stage 2, so that the average of the two values was regarded as before intervention.

Of the respondents, $33(82.5 \%)$ were not able to keep the transcript of the routine initially described, requiring at least one intervention each to undertake the revision report. The most common interventions $(30 ; 75.0 \%)$ were related to changing the interval between doses and possible drug-food interactions $(13 ; 32.5 \%)$. 
TABLE IV - Influence of pharmacotherapy review upon the characteristics of treatment, medication adherence and blood pressure control of the study participants $n=40$

\begin{tabular}{lccc}
\hline Variables & Before intervention & After intervention & $\boldsymbol{p}$-value \\
\hline Adherent subjects & & & \\
Morisky-Green test - $\mathrm{n}(\%)$ & $15(37.5)$ & $30(75.0)$ & $<0.001^{\mathrm{a}}$ \\
Self-report - $\mathrm{n}(\%)$ & $28(70.0)$ & $37(92.5)$ & $0.004^{\mathrm{a}}$ \\
Reported adherence score - $\bar{X}(\mathrm{SD})$ & $8.2(1.7)$ & $8.9(1.0)$ & $<0.001^{\mathrm{b}}$ \\
Controlled blood pressure - $\mathrm{n}(\%)$ & $21(52.5)$ & $31(77.5)$ & $0.006^{\mathrm{a}}$ \\
Systolic blood pressure reading $-\bar{X}(\mathrm{SD})$ & $136.0(22.1)$ & $125.0(26.3)$ & $<0.001^{\mathrm{c}}$ \\
Diastolic blood pressure reading $-\bar{X}(\mathrm{SD})$ & $84.5(14.2)$ & $80.0(15.7)$ & $0.002^{\mathrm{b}}$ \\
Number of doses $-\bar{X}(\mathrm{SD})$ & $5.6(3.6)$ & $5.9(3.9)$ & $0.039^{\mathrm{b}}$ \\
Number of intakes $-\bar{X}(\mathrm{SD})$ & $2.8(1.1)$ & $3.2(1.3)$ & $0.025^{\mathrm{b}}$ \\
\hline $\bar{X}-\mathrm{m}$
\end{tabular}

$\overline{\bar{X}}$ - mean; SD - standard deviation; ${ }^{\mathrm{a}} \mathrm{McNemar}$ test, ${ }^{\mathrm{b}}$ Wilcoxon test; ${ }^{\mathrm{c}}$ Paired $\mathrm{t}$ test.

During the last meeting, patients were asked about the place where they kept the intervention report. Seventeen $(42.5 \%)$ of them kept near the drugs, nine $(22.5 \%)$ used magnets to post on the refrigerator door, eight $(20.0 \%)$ had saved elsewhere together with exams and prescriptions, and six (15.5\%) did not remember where they had kept the report.

Furthermore, we investigated the perception of respondents regarding the role of intervention upon the adherence to treatment. The majority $(87.5 \%)$ considered the intervention as a positive contribution to improve medication use.

\section{DISCUSSION}

The sociodemographic profile observed in this study was similar to that found in other studies on adherence to hypertension treatment (Trauthman et al., 2014; SantaHelena, Nemes, Neto-Eluf, 2008), mainly regarding low education and age group, which were cited as factors affecting adherence to therapy, since they were crucial in the understanding of the information received (Nair et al., 2011; Vrijens et al., 2008; WHO, 2003).

Among the non-pharmacological measures, the most often cited by participants was the control of sodium intake. This control is positive, because sodium intake is directly related to increased blood pressure, which is corroborated by Pierin and colleagues, who evaluated hypertension control and associated factors (Pierin et al., 2011). However, the present study did not investigate whether the non-pharmacological measures were adequate for the control of blood pressure levels.

The nosological profile of the participants was in line with other studies (Trauthman et al., 2014; Bastos-Barbosa et al., 2012; Acúrcio et al., 2009), since it was related mainly to other common problems such as metabolic syndrome, diabetes and dyslipidemia (SBC, 2010).

As for the pharmacotherapeutic profile, since it was a group of hypertensive patients, most were poli-medicated and used different therapeutic classes for the management of health problems. However, there was a low prevalence use of antiplatelet drugs, such as acetylsalicylic acid, recommended by the $6^{\text {th }}$ Arterial Hypertension Guideline (Sociedade Brasileira de Cardiologia, 2010). This finding may reflect a limitation of the study since medication reconciliation was not carried out through consultation of medical records. If they were not prescribed, the need for these products should be assessed, and interventions to improve prescribing should be made. When the drugs were evaluated according to their anatomical groups, they were similar to other studies (Trauthman et al., 2014; Acúrcio et al., 2009) that evaluated medication complexity prescribed for elderly people.

The intervention performed in this study is contextualized within the pharmaceutical and clinical services and is part of the pharmacotherapy review (Leikola et al., 2012; Geurts et al., 2012; Holland et al., 2007). Drug administration schedule discussed here reflects the organization of the patients' routine indicating the best schedule for medication management and addressing issues related to safety and effectiveness (Leikola et al., 2012).

Information contained in medical prescriptions, follow-up cards and patient's report without consulting the medical records can generate outdated information and omission of prescribed medications. In Brazil, dispensing pharmacies do not have access to computerized patient records. Although they are not the most reliable sources of information, they are the only available reference.

All unusual doses of medications were clarified with 
the patient prior to issuing the review report. The proposed report, therefore, presented ways to fit the medication regimen into the patients' routines. For most patients, the report diverged from the way the drugs were taken. The reasons for this intervention were particularly related to the need to respect the intervals of drug administration, the number of doses, effectiveness of treatment (e.g., statins administered in a single dose and long before bedtime), or avoid food-drug interactions (e.g., captopril when associated with food). Such changes have also been made in the study by Silva and colleagues who evaluated the pharmaceutical care services to optimize therapeutic outcomes in hypertensive subjects (Silva et al., 2008).

The intervention performed increased significantly adherence rates among patients when assessed by both the self-reported adherence and the Morisky-Green test. These findings were in agreement with studies (Skowron, Polak, Brandys, 2011; Nobre, Ribeiro, Mion, 2010; Sociedade Brasileira de Cardiologia, 2010; Prado, Kupek, Mion, 2007; Lyra et al., 2007) showing that pharmaceutical interventions intended to increase motivation and adherence to treatment help improve medication adherence.

In a study conducted by Nobre, Ribeiro and Mion on blood pressure control in Brazil (Nobre, Ribeiro, Mion, 2010), the number of patients with controlled blood pressure was similar to that found in this study before the intervention. Analysis of blood pressure readings before and after the intervention revealed that pharmaceutical intervention improved control of blood pressure, which is in agreement with the $6^{\text {th }}$ Brazilian Guidelines on Hypertension (Sociedade Brasileira de Cardiologia, 2010), meaning that adherence to treatment changes the disease control (Skowron, Polak, Brandys, 2011; Vrijens et al., 2008; Silva et al., 2008).

Moreover, interventions significantly increased the number of daily doses and the number of drug intakes per day. To a certain extent, interventions increased treatment complexity (Acúrcio et al., 2009). Thus, it is suggested that all medication schedules should be regularly prepared by prescribers, especially pharmacists. Preferably, this service must be redone at every change in treatment, even if temporarily. In this case, they should always be preceded by medication reconciliation (Geurts et al., 2012).

Effective and safe medication schedules should ideally be held from the beginning of treatment (Chemello et al., 2014), not as a means of correcting safety and effectiveness problems observed after the incorrect use. It is believed that once a patient develops a habit of using the medication incorrectly, it is more difficult to readapt to the correct use and avoid health risks.
This study did not aim to make economic analyzes such as those conducted by Obreli-Neto et al. (2015) and Correr et al. (2009), but those studies show that pharmaceutical services are financially viable for the prevention of harm to patients with chronic diseases. Recently, Houle et al. (2014) presented the costs of pharmacotherapy review services in different countries demonstrating costs from US\$ 42.16 to 150.00 per encounter depending on the complexity of the case and the location of the service. In the same context, Chinthammit et al. (2015) asserted that the probability of avoiding a preventable adverse drug effect (ADE) is $0.93(95 \%$ CI 0.91-0.95), and the cost of treating a preventable ADE is between US\$ 116.87 and US\$ $10,056.44$. To these authors, the ADE can be the ineffective action of medicines. From this information, even without a specific economic analysis, it is plausible to suppose that the medication review is cost-effective for the management of hypertension. However, news studied will be conducted for this purpose.

Limitations of this study included the fact that the source of information about medications used by patients was not controlled, and the influence of non-pharmacological measures was not investigated. Furthermore, even patients with comorbidities presented a pressure goal with values less than 140/90 $\mathrm{mm} \mathrm{Hg}$. Another limitation was related to data analysis, because we did not control several factors involved in blood pressure control beyond adherence, such as the choice of medicines and time of diagnosis. It was also not the aim of this study to analyze the inappropriate choice of therapy. However, even with these limitations, evidence was found to demonstrate the importance of pharmaceutical interventions in improving medication adherence and blood pressure control.

\section{CONCLUSION}

Review pharmacotherapy service developed in this study could significantly promote increased adherence to medication and blood pressure control, even if they increase the complexity of treatment, due to the larger number of drug doses and daily intakes.

In addition, the pharmacotherapy review can identify, prevent and resolve drug-related problems, minimizing incidents and reducing adverse effects.

Further development of pharmacotherapy review is required to implement these services in community pharmacies. Nonetheless, there is a clear need for these services, due to the outcome of morbidity and mortality rates related to hypertension and other chronic diseases. 


\section{ACKNOWLEDGEMENTS}

The authors would like to thank the patients who participated in this study and the employees of the community pharmacy where this investigation was carried out.

\section{REFERENCES}

ACÚRCIO, F.A.; SILVA, A.L.; RIBEIRO, A.Q.; ROCHA, N.P.; SILVEIRA, M.R.; KLEIN, C.H.; ROZENFELD, S. Complexidade do regime terapêutico prescrito para idosos. Rev. Assoc. Med. Bras., v.4, n.55, p.468-474, 2009.

BASTOS-BARBOSA, R.G.; FERRIOLLI, E.; MORIGUTI, J.C.; NOGUEIRA, C.B.; NOBRE, F.; UETA, J.; LIMA, N.K.C. Treatment adherence and blood pressure control in older individuals with hypertension. Arq. Bras. Cardiol., v.99, n.1, p.636-641, 2012.

BEN, A.J.; NEUMANN, C.R.; MENGUE, S.S. The Brief Medication Questionnaire and Morisky-Green Test to evaluate medication adherence. Rev. Saúde Pública. v.2, n. 46, p. $279-289,2012$.

BRASIL. Ministério da Saúde. Farmácia Popular do Brasil. Available at: $<$ http://portalsaude.saude.gov.br/index.php/oministerio/principal/secretarias/sctie/farmacia-popular>. Accessed on: Jan. 2015.

CHINTHAMMIT, C.; ARMSTRONG, E. P.; MARTIN, R.; WARHOLAK, T. Cost-Effectiveness of Comprehensive Medication Reviews Versus Noncomprehensive Medication Review Interventions and Subsequent Successful Medication Changes in a Medicare Part D Population. $J$. Manag. Care Spec. Pharm., v.21, n.5, p.381-389, 2015.

CHEMELLO, C.; SOUZA, F.; PATRICIO, E. S.; FARIAS, M.R. Pharmaceutical care as a strategy to improve the safety and effectiveness of patients pharmacotherapy at a pharmacy school: a practical proposal. Braz. J. Pharm. Sci., v.50, n.1, p.185-193, 2014.

CORRER, C.J.; PONTAROLO, R.; WIENS, A.; ROSSIGNOLI, P.; MELCHIORS, A.C.; RADOMINSKI, R.; FERNANDEZLLIMÓS, F. Economic evaluation of pharmacotherapeutic follow-up in type 2 diabetes mellitus patients in community pharmacies. Arq. Bras. Endocrinol. Metabol. v.53, n.7, p.825-833, 2009.
CORRER, C.J.; SOLER, O.; OTUKI, M.F. Assistência farmacêutica integrada ao processo de cuidado em saúde: gestão clínica do medicamento. Rev. Pan-Amaz. Saúde, v.2, n.3, p.41-49, 2011.

GEURTS, M.M.E.; TALSMA, J.; BROWERS, J.R.B.J.; GLER, J.J. Medication review and reconciliation with cooperation between pharmacist and general practitioner and the benefit for the patient: a systematic review. Br. J. Clin. Pharmacol., v.74, n.1, p.16-33, 2012.

HO, P.M.; BRYSON, C.L.; RUMSFELD, J.S. Medication Adherence: its importance in cardiovascular Outcomes. Circulation, v.119, n.23, p.3028-3035, 2009.

HOLLAND, R.; DESBOROUGH, J.; GOODYER, L.; HALL, S.; WRIGHT, D.; LOKE, Y.K. Does pharmacist-led medication review help to reduce hospital admissions and deaths in older people? A systematic review and metaanalysis. Br. J. Clin. Pharmacol., v.65, n.3, p.303-316, 2007.

HOLT, E.W.; MUNTNER, P.; JOYCE, C.J.; WEBBER, L.; KROUSEL-WOOD, M.A.; Health-related quality of life and antihypertensive medication adherence among older adults. Age Ageing, v.39, n.4, p.481-487, 2010.

HOULE, S.K.D.; GRINDOD, K.A.; CHATTERLEY, T.; TSUYUKI, R.T. Paying pharmacists for patient care: A systematic review of remunerated pharmacy clinical care services. Can. Pharm. J. (Ott), v.147, p.209-232, 2014.

INSTITUTO BRASILEIRADE GEOGRAFIAE ESTATÍSTICA. IBGE.Cidades@,2010. Available at: <http://www.ibge.gov. $\mathrm{br} /$ cidadesat/link.php?codmun $=421545>$. Accessed on: Jan. 2015.

KOENIGSFELD ,C.F.; HORNING, K.K.; LOGEMANN, C.D.; SCHMIDT, G.A. Medication therapy management in the primary care setting: a pharmacist-based pay-or-performance project. J. Pharm. Pract., v.25, n.1, p.89-95, 2012.

LEIKOLA, S.; TUOMAINEN, L.; PEURA, S.; LAURIKAINEN, A.; LYLES, A.; SAVELA, E.; AIRAKSINEN, M. Comprehensive medication review: development of a collaborative procedure. Int. J. Clin. Pharm., v.34, n.4, p.510-514, 2012.

LUNELI, R.P.; PORTAL, V.L.; ESMÉRIO, F.G.; MORAES, M.A.; SOUZA, E.N. Adesão medicamentosa e não medicamentosa de paciente com doença arterial coronariana. Acta. Paul. Enferm., v.22, n.4, p.367-373, 2009. 
LYRA, J.R.D.P.; ROCHA, C.E.; ABRIATA, J.P.; GIMENES, F.R.E.; GONZALES, M.M.; PELÁ, I.R. Influence of Pharmaceutical Care Intervention and communication skills on the improvement of pharmacotherapy outcomes with elderly Brazilian outpatients. Patient Educ. Couns., v.68, n.2, p.186-192, 2007.

MIRANDA, T.M.M.; PETRICCIONE, S.; FERRACINI, F.T.; BORGES-FILHO, W.M. Intervenções realizadas pelo farmacêutico clínico na unidade de emergência. Einstein, v.10, n.1, p.74-80, 2012.

MORISKY, D.E.; GREEN, L.W.; LEVINE, D.M. Concurrent and predictive validity of a self-reported measure of medication adherence. Med. Care, v.24, n.1, p.67-74, 1986.

NAIR, K.V.; BELLETTI, D.A.; DOYLE, J.J.; ALLEN, R.R.; MCQUEEN, R.B.; SASEEN, J.J.; GRIEND, J.V.; PATEL, J.V.; MCQUEEN, A.; JAN, S. Understanding barriers to medication adherence in the hypertension population by evaluating responses to a telephone survey. Patient Prefer. Adher, v.5, p.195-206, 2011.

NOBRE, F.; RIBEIRO, A.B.; MION, J.R.D. Controle da pressão arterial sob tratamento anti-hipertensivo no Brasil - Controlar Brasil. Arq. Bras. Cardiol., v.94, n.5, p.663670, 2010.

OBRELI-NETO, P.R.; MARUSIC, S.; GUIDONI, C.M.; BALDONI, A.D.E.O.; RENOVATO, R.D.; PILGER, D.; CUMAN, R.K.; PEREIRA, L.R. Economic evaluation of a pharmaceutical care program for elderly diabetic and hypertensive patients in primary health care: a 36-month randomized controlled clinical trial. J. Manag. Care Spec. Pharm. v.21, n.1, p.66-75, 2015.

OSTERBERG, L.; BLASCHKE, T. Adherence to Medication. N. Engl. J. Med., v.353, p.487-497, 2005.

PIERIN, A.M.G.; MARRONI, S.N.; TAVEIRA, L.A.F.; BENSEÑOR, I.J.M. Controle da hipertensão arterial e fatores associados na atenção primária em Unidades Básicas de Saúde localizadas na Região Oeste da cidade de São Paulo. Ciênc. Saúde Colet., v.16, n.1, p.1389-1400, 2011.

PORTO, T. M.; MACHADO, D.C.; MARTINS, R.O.; GALATO, D.; PIOVEZAN, A.P. Locus of pain control associated with medication adherence behaviors among patients after an orthopedic procedure. Patient Prefer. Adher., v.8, p.991-995, 2014.
PRADO, J.C.; KUPEK, E.; MION, J.R.D. Validity of four indirect methods to measure adherence in primary care hypertensives. J. Hum. Hypertens., v.21, p.579-784, 2007.

SANTA-HELENA, E.T.; NEMES, M.I.B.; NETO-ELUF, J. Development and validation of a multidimensional questionnaire assessing non-adherence to medicines. Rev. Saúde Pública, v.42, n.4, p.764-767, 2008.

SILVA, A.S.; LYRA, J.R.D.P.; MUCCINI, T.; NETO, P.G.S.G.; SANTANA, D.P. Avaliação do serviço de atenção Farmacêutica na otimização dos resultados terapêuticos de usuários com hipertensão arterial sistêmica: um estudo piloto. Rev. Bras. Farm. v.89, n.3, p.255-258, 2008.

SKOWRON, A.; POLAK, S.; BRANDYS, J. The time of pharmaceutical care on patients with hypertension and their pharmacists. Pharm. Prac., v.9, n.2, p.110-115, 2011.

SOCIDADE BRASILEIRA DE CARDIOLOGIA. SBC. VI Diretrizes Brasileiras de Hipertensão. Arq. Bras. Cardiol., v.95, n.1, p.1-51, 2010.

TRAUTHMAN, S.C.; PIOVEZAN, A.P.; BECKER, I.R.T.; MARTIN, L.P.; GALATO, D. Pharmacotherapy for hypertension and diabetes in a national health care system in Brazil: emphasis on patient access to prescription medications. Lat. Am. J. Pharm., v. 33, n.3, p.492-8, 2014

VRIJENS, B.; VINCZE, G.; KRISTANTO, P.; URQUHART, J.; BURNIER, M. Adherence to prescribe antihypertensive drug treatments: longitudinal study of electronically compiled dosing histories. B.M.J., v.336, p.1114-1117, 2008.

WORLD HEALTH ORGANIZATION. WHO. International Classification of Diseases (ICD). 2010. Avaiable at: $<$ http:// www.who.int/classifications/icd/en/>. Accessed on: Jan. 2015.

WORLD HEALTH ORGANIZATION. WHO. Adherence to long-term therapies: evidence for action. Switzerland: World Health Organization, 2003. Available at: <http:// whqlibdoc.who.int/publications/2003/9241545992.pdf>. Accessed on: Jan. 2015.

WORLD HEALTH ORGANIZATION. WHO. The ATC classification structure and principles, 2015. Available at: $<$ http://www.whocc.no/atcddd $>$. Accessed on: Jan. 2015.

Received for publication on $01^{\text {st }}$ January 2015 Accepted for publication on $06^{\text {th }}$ September 2015 
